\title{
NEW COGNITIVE ENVIRONMENTS FOR SURVEY RESEARCH IN THE AGE OF SCIENCE II
}

Karl H. MÜLLER

Wiener Institute for Social Science Documentation and Methodology (WISDOM), Wien

Niko TOŠ

Faculty of Social Sciences, Ljubliana

UDK: 303.62:001

$$
001.891
$$

Izvorni znanstveni rad

Primljeno: 29. 11. 2010.

This article deals with a rapid change which is currently sweeping through the science landscapes and discusses the far-reaching implications of this structural break for the social sciences and for survey research in particular. More specifically, this article will make three central claims. First, the science system as a whole is presently undergoing a significant phase transition which can be summarized as a shift from Science I to Science II. Second, due to these large-scale changes, new cognitive environments are gradually emerging as the background knowledge of survey research which will exert a profound impact on its future practices. Third, these new cognitive environments will lead to new actor models and to new bridges between survey research and the cognitive neurosciences on the one hand and biomedical research on the other hand.

Keywords: long-term dynamics of science, cognitive neurosciences, background knowledge, survey research, biomedical research

$\triangle \quad$ Karl H. Müller, Wiener Institute for Social Science Documentation and Methodology (WISDOM), Liechtensteinstraße 22a/2/17, A-1090 Wien, Austria. E-mail: mueller@wisdom.at

The present article starts from a bird's eye view on scientific landscapes and on their evolution in the very long run. From this macro-scientific perspective of the très longue durée it can 
DRUŠ. ISTRAŽ. ZAGREB GOD. 21 (2012)

BR. 2 (116),

STR. 315-339

MÜLLER, K. H., TOŠ, N.: NEW COGNITIVE.. be observed that a deep structural change is currently taking place which affects the disciplinary matrices (Kuhn, 1973, 1977) as well as the cognitive co-operation potentials of practically all major disciplines across the natural, social and technical sciences. ${ }^{1}$ Quite naturally, such a comprehensive phase transition should exert a deep impact on the social sciences and on their boundaries or links with neighbouring or seemingly distant academic fields. In particular, the relevant background knowledge for the social sciences in general or for special areas like survey research in particular should be changing significantly. In the subsequent sections of this article some of the implications of this on-going metamorphosis in the science landscapes for the area of survey research will be outlined in greater detail. As its central claim, the article suggests that the current changes in the background knowledge of survey research should have a strong influence in re-shaping and re-inventing survey research significantly.

\section{FROM SCIENCE I TO SCIENCE II}

Within the last decades, the science system as a whole has entered a phase of radical transformations from an old regime, called Science I, to a new regime under the name of Science II. ${ }^{2}$ This general change will lead to profound changes in the theoretical and epistemological background knowledge for the social sciences in general and for survey research in particular. ${ }^{3}$

Table 1 captures some of the important shifts from the traditional cognitive organizations of science which were characteristic of the scientific method from the 16th and 17th cen-

(1) TABLE 1

Main Distinctions between Science I and Science II turies onward to its new rules of operation and to the new model and theory structures which emerged rapidly since the 1950s.

\begin{tabular}{lll}
\hline Dimensions & Science I & Science II \\
\hline Leading Fields of Science & Classical Physics & $\begin{array}{l}\text { Evolutionary Biology and } \\
\text { the Sciences of Complexity }\end{array}$ \\
Theoretical Goals & General, Universal Laws & $\begin{array}{l}\text { Pattern Formation and } \\
\text { Pattern Recognition }\end{array}$ \\
Theoretical Perspectives & Axiomatic, Reductionistic & $\begin{array}{l}\text { Nested and Embedded Processes } \\
\text { Leading Metaphors }\end{array}$ \\
Core Philosophers & Clocks & Clouds \\
Epistemology & Observer Excluded & Ludwig Wittgenstein (Cogitamus) \\
Ontology & $\begin{array}{l}\text { Dualism } \\
\text { (res cogitans/res extensa) }\end{array}$ & Observer Included \\
() & Monism, Self-Organization
\end{tabular}




\begin{tabular}{lll} 
Dimensions & Science I & Science II \\
\hline Generative Mechanisms & Trivial Mechanisms & Non-Trivial Mechanisms \\
Forecasting Capabilities & High & Low \\
Complexity & Low & High \\
Perspectives on Change & Linear, Equilibrium & Non-Linear, far from Equilibrium \\
$\begin{array}{l}\text { Distributions } \\
\text { Potential for Inter- }\end{array}$ & Emphasis on Mild Distributions & Emphasis on Wild Distributions \\
$\begin{array}{l}\text { Disciplinary Research } \\
\begin{array}{l}\text { Cognitive Distances } \\
\text { between the Social }\end{array}\end{array}$ & High & High \\
$\begin{array}{l}\text { Sciences and the Lea- } \\
\text { ding Field of Science }\end{array}$ & & Medium/Small \\
\end{tabular}

\section{SIGNIFICANT CHANGES IN THE BACKGROUND KNOWLEDGE FOR SURVEY RESEARCH IN THE AGE OF SCIENCE II}

Before entering into content issues, the concept of a background knowledge (BK) for a scientific discipline SDi must be introduced in a clear and accessible manner. In a general way, the theoretical, epistemological and methodological background knowledge for a scientific discipline SDi is composed of building blocks from three different domains.

- The first class of background knowledge elements (BKI) for a scientific discipline SDi or field of analysis is based on those disciplines that can be assumed to constitute or form the basis of SDi. With respect to the social sciences or the particular field of survey research, the cognitive neurosciences (CNS) can be seen as the constitutive background knowledge area for the social sciences or, more specifically, for survey research. Here, the model and theory structures of CNS, its prevalent epistemologies and its dominant methodologies are all included in the BKI-group for the social sciences or for survey research.

- The second set of BK-building blocks (BKII) comes from the leading field ( $\mathrm{LDt}$ ) at a given time $\mathrm{t}$, the theory structures of LDt, its dominant epistemologies and its general methodologies. Thus, the life-sciences and their mode of operations ${ }^{4}$ constitute the second BKII-group for the social sciences or for survey research.

- The third and final group of background-knowledge building blocks (BKIII) is transdisciplinary in nature and ap- 
DRUŠ. ISTRAŽ. ZAGREB GOD. 21 (2012),

BR. 2 (1 16$)$

STR. 315-339

MÜLLER, K. H., TOŠ, N.: NEW COGNITIVE.. plies to all scientific disciplines, including the leading discipline as well. Paradigmatically, the third BK-group is composed of a semantic network with universal categories like space, time, matter, energy or information, of a system of constants across the natural and social worlds, of basic logical and numerical calculi and of general rules for scientific operations across all relevant scientific disciplines.

In the days of Science I with theoretical physics as the leading scientific field, the search for universal laws or a reductionist view of theory structures with theoretical physics as its basis were typical elements of the theoretical background knowledge for the social sciences in general or for survey research in particular. Likewise, epistemological or methodological rules, associated with theoretical physics like objectivity, scientific realism or the covering law model of explanations became characteristic building blocks for the background-knowledge of the social sciences.

Currently, we live amidst the diffusion of Science II, with the life sciences as the leading field and with its corresponding epistemologies or methodologies. In the context of Science II the theoretical, epistemological and methodological background-knowledge for scientific disciplines outside the leading field of the life sciences is undergoing significant changes, too. In a single catch-phrase, the transitions in background knowledge can be summarized as a shift from a vertically grounding background knowledge to a horizontally embedding one or, in line with Table 1, from a hierarchically structured background knowledge to a heterarchical one (Müller, 2011).

At this point, the article will be focused on those changes in the background knowledge which are of particular relevance for survey research. In a nutshell, at least seven building blocks can be identified both from the area of the life sciences (BKII) and from the embedding domains of the neuro-cognitive sciences $\left(\mathrm{BK}^{\mathrm{I}}\right)$ which should exert a strong influence on the future forms of models, methods and instrument constructions in survey research. As will be shown later on in more detail, the new background knowledge should have sustainable effects on internal, non-trivial actor models which should replace the current trivial versions, on more complex external actor models and their interactions with their environments as well as on the links between survey research and the biomedical sciences. Table 2 as well as Figure 1 summarize those changes in background knowledge that should exert a significant impact on survey research. 


\begin{tabular}{|c|c|c|}
\hline $\begin{array}{l}\text { Domains of Back- } \\
\text { ground Knowledge }\end{array}$ & $\begin{array}{l}\text { Science I } \\
\text { [Theoretical Physics } \\
\text { as Leading Discipline (LD)] }\end{array}$ & $\begin{array}{l}\text { Science II } \\
\text { [Life Sciences as LD] }\end{array}$ \\
\hline \multirow[t]{2}{*}{$\begin{array}{l}\text { Objects of } \\
\text { Investigation }\end{array}$} & $\begin{array}{l}\text { Objects } \\
\text { Simple Action Schemes }\end{array}$ & $\begin{array}{l}\text { Living Systems } \\
\text { Embedded Cognition }\end{array}$ \\
\hline & $\begin{array}{l}\text { Cognitive Isolationism } \\
\text { Single Account Sufficient }\end{array}$ & $\begin{array}{l}\text { Cognitive Holism } \\
\text { Requisite Variety Necessary }\end{array}$ \\
\hline Subjects of Investigation & Observer Exclusion & Observer Inclusion \\
\hline $\begin{array}{l}\text { Interactions } \\
\text { (between Subjects } \\
\text { and Objects) }\end{array}$ & $\begin{array}{l}\text { Sequential, Linear } \\
\text { Equilibrium } \\
\text { Dyadic, Asymmetric } \\
\text { Forms }\end{array}$ & $\begin{array}{l}\text { Recursive, Non-Linear } \\
\text { Eigenforms } \\
\text { Triadic, Symmetric } \\
\text { Configurations }\end{array}$ \\
\hline
\end{tabular}

(1) TABLE 2

Changes in the Theoretical, Epistemological and Methodological Background Knowledge of Science I and Science II
D FIGURE 1

The Emerging Epistemological, Methodological and Theoretical Science II Background for Survey Research
As can be seen both from Figure 1 and from Table 2, the main differences between the old and the new background knowledge cover the entire domain of analyses, namely the subjects of investigation, the objects of analysis and, finally, the interaction modes between subjects and objects of analysis. All three domains differ strongly between Science I and Science II. In short, Science II has become a science of living systems for living systems in which the subjects of analysis, being living systems themselves, are an indispensable and inclusive part of an investigation. The objects of analysis, namely living systems, turn out to be far more complex than the physical objects within Science I. Finally, the interactions between subjects and objects are organized, as will be shown later, in a closed triadic as well as recursive manner.

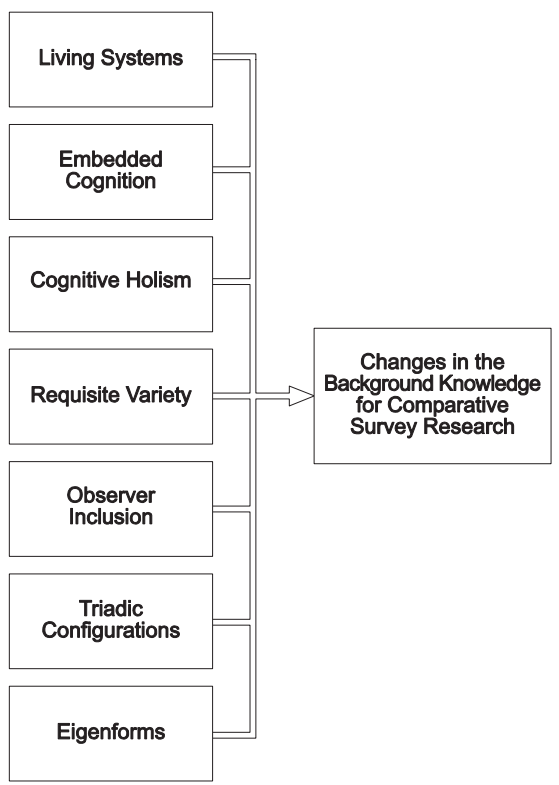


DRUŠ. ISTRAŽ. ZAGREB GOD. 21 (2012), BR. 2 (116),

STR. 315-339

MÜLLER, K. H., TOŠ, N.: NEW COGNITIVE..
The methodological and theoretical elements of the new background knowledge emerge predominantly from the embedding area for the social sciences, namely from the cognitive neurosciences whereas the new epistemological components come from a diverse group of frameworks which are particularly focused on the specificities of living systems like the approaches by Robert Rosen (2005) and Walter M. Elsasser (1998), radical constructivism or, as specially relevant subsets of radical constructivism,, 5 second-order cybernetics (esp. Foerster, 2003) and the autopoietic approach (Maturana, 1985a; Maturana and Varela, 1987). These and similar perspectives are especially relevant for shaping the core epistemologies of Science II research. ${ }^{6}$ From both sides, the theoretical-methodological and the epistemological one, the conventional wisdom of survey research is not only questioned in its core aspects and in its central designs (see, for example, Palombo, 1999; Ryckman, 2000), but survey research is also very much encouraged to change its traditional perspectives in order to become compatible with the new Science II landscapes.

\section{SEVEN NEW COMPONENTS IN THE BACKGROUND KNOWLEDGE FOR SURVEY RESEARCH IN THE AGE OF SCIENCE II}

Following Figure 1 and Table 2, the first distinctive feature between the background knowledge BKI-II of Science I and Science II lies in the units of analysis and has been captured by the dichotomy of objects (Science I) and living systems (Science II). As it turns out, living systems, as the main actors on the stage of Science II, are structured and organized in a significantly different way than the physical objects in the phase of Science I. Living systems can be characterized by attributes like autonomy, internal state-determination, multi-level organization, learning and the like. The most important differences to the objects under Science I lie, however, in the relations between a researcher and her or his domain of investigation. Under Science I, objects and researchers were situated in different ontological domains whereas under Science II, the researcher her- or himself is a living system, too, and can be described with categories like autonomy, internal state-determination, multi-level organization, learning and the like. This point has far-reaching implications, some of which will be dealt with under the notion of observer inclusion (See, once again, Figure 1).

Aside from an analytical distinction in terms of living actors, a second new element in the theoretical background knowledge BKI-II for survey research is related to the description of the environments of living systems which should be conceptualized in a significantly different way, too. In Sci- 
DRUŠ. ISTRAŽ. ZAGREB GOD. 21 (2012), BR. 2 (116),

STR. 315-339

MÜLLER, K. H., TOŠ, N. NEW COGNITIVE...

2 TABLE 3

The Changing Roles of Environments between Science I and Science II ence I, physical objects could be studied as embedded in a physical environment and with directly observable interactions between objects and their surroundings. Under Science II, cognitive models and methodologies must follow more and more along the pathways of embedded or situated cognition (see esp. Adams and Aizawa, 2008; Bodenhausen and Lambert, 2003; Gibbs, 2005; Noe, 2009 or Robbins and Aydede, 2008). This road towards embedded or situated cognition is so important because it puts special emphasis on the distributed nature of cognition, on thinking environments and why, following a well-known reversion by Humberto R. Maturana, the mind is not the head (Maturana, 1985).

In situated cognition, a brain needs not only a senso-motoric active organism, but also a responsive environment for its own internal cognitive operations. In this view, the environment becomes the necessary co-evolving counterpart for individual actions and interactions. Table 3 exhibits some of the characteristic differences between the two forms of environments in Science I and in Science II.

\begin{tabular}{ll}
\hline Environments in Science I & Environments in Science II \\
\hline Weak Boundaries & Strong Boundaries \\
Direct Crossings & Indirect Crossings \\
Cause - Effect & Triadic Relations \\
Direct Environmental Effects & Boundary Transformations, \\
External Dynamics & Indirect Effects \\
Adaptation & Internal Dynamics \\
\end{tabular}

Cognitive holism becomes the third new component of the background knowledge BKI-II for survey research, but will be introduced in more detail in the next section because the building block of cognitive holism offers a new bridge from the cognitive neurosciences to the inner side of actor models.

The fourth point of departure between the old and the new background knowledge BKI-II moves away from the descriptive requirements for living systems and their environments or from the theoretical requirement of a holistic organization of cognitive theories. Instead, the fourth point emphasizes the importance of a requisite descriptive and data variety. Under Science II, the focus shifts away from descriptions and measurements at a single level to more general configurations and, above all, to different levels of descriptive and data variety. The study of living systems requires a multiplicity of data sources which cover the entire range of mea- 
DRUŠ. ISTRAŽ. ZAGREB GOD. 21 (2012), BR. 2 (116)

STR. 315-339

MÜLLER, K. H., TOŠ, N.: NEW COGNITIVE... surements, ranging from the cellular and neural level, to high-level brain measurements, up to the levels of internal or external verbal accounts or the observations of acting and interacting persons and transactional data in the case of human societies. All these different levels, measurement types and data formats are needed in order to reach a fuller understanding of living systems in their contexts or environments.

The most important challenge with respect to the requisite variety of measurements and observations will be to bridge the currently deep gap between behavioral observations and the level of the brain scans and neural measurements. But Science II, in contrast to Science I, will generate a rich flow of neural and brain data not only on different types of thought processes, but on daily routines and practices as well. For comparative survey research, this new stage of a requisite descriptive data variety will bring about a dense stream of neural patterns and data for the different stages in survey interactions, which should allow tackling classical issues and controversies like the one on non-attitudes or under-learned responses in a fresh manner.

Fifth, aside from the requisite descriptive variety, another epistemological point of considerable relevance for Science II research in general lies in the inclusion of observers or, alternatively, of researchers in their research. Focused on survey research in particular, research designs will change more and more from an exclusive to an inclusive mode, with social researchers as an indispensable element in it.

In the world of Science I, mass, space and energy were the fundamental building blocks for a science of objects. Warren McCulloch was probably the first to note the peculiarity that breakthroughs in physics require the invention of surprising regularities or theorems of great abstraction which, however, are not included in the conceptual machinery for physical objects.

Let us now compel our physicist to account for himself as a part of the physical world. In all fairness, he must stick to his own rules and show in terms of mass, energy, space and time how it comes about that he creates theoretical physics. (McCulloch, 1988, 73)

Thus, in Science II one is, by necessity, confronted with a more inclusive task. Following, once again, McCulloch, a physicist

must then become a neurophysiologist ..., but in so doing he will be compelled to answer whether theoretical physics is something which he can discuss in terms of neurophysiology ... To answer 'no' is to remain a physicist undefiled. To answer 'yes' is to become a metaphysician. (Ibid.) 
DRUŠ. ISTRAŽ. ZAGREB GOD. 21 (2012), BR. 2 (116)

STR. 315-339

MÜLLER, K. H., TOŠ, N. NEW COGNITIVE...

$\vartheta$ FIGURE 2

Triadic and

Generatively Closed

Research Designs
In other words, Science II is the era of living systems, being researched by living systems. This new configuration brings the observer or the researcher as a necessary component back into her or his research domain. Thus, Science II becomes to a remarkable extent a self-referential and self-inclusive form of science.

Sixth, another element of the new background knowledge BKI-II for survey research lies in the closed organization of relations into which living systems, the observing scientist included, can and should enter. In Science II, the new minimal configuration for the study of living or learning systems by living systems is not a dyadic relation between subject and object which has been characteristic of the conventional scientific method, but is built in a triadic fashion, with the observing scientific researcher as one node, the domains under observation as another node and with a final node linking and closing these two nodes to a triadic ensemble. In short, Science II research designs are to be built in their minimal form not with one, not with two, but with three components.?

Science II, in contrast to Science I, will be characterized more and more by designs and by operations in configurations of a closed triadic nature which includes the observing researcher R, the domain under observation which is usually composed of observing living systems or, alternatively, of participant observers PO. Additionally, R and PO are closed by an inter-mediate element such as rule systems or theories about the neural organization of $\mathrm{PO}$ and $\mathrm{R}$ which acts as a generative mechanism GM between $\mathrm{R}$ and PO.

Characteristically, the types of relations in triadic configurations change from causal relations to generative relations. Figure 2 as well as Table 4 highlight the significant differences between the causal forms of Science I and the generative configurations of Science II.

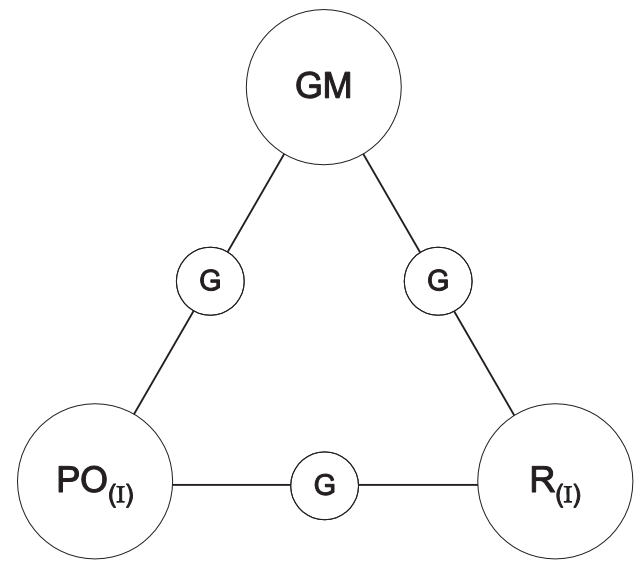


Asymmetrical in time

Separation into cause and effect

Cause is necessary, sufficient or both

Observers excluded

Non-recursive

Openness

Generalizations
Symmetrical in time

No causes and effects

Mutual dependence

Observers included

Recursive

Closure

Necessary Eigenforms

*A, B: Events. PO: Observer. GM: Generative Mechanism. LS: Living Systems as Field of Research.

Seventh, Table 4 already included the notion of necessary Eigenforms, inherent in triadic and generative configurations. Thus, the seventh ingredient of the new background knowledge BKI-II emphasizes the production of Eigenforms. This implies that the recursive interactions between researchers and their living fields of investigation, if properly organized in a triadic fashion, lead to new stabilities or, to use an expression by Heinz von Foerster, to Eigenforms. Eigenforms become one of the central goals of research processes within Science II. ${ }^{8}$

The remaining sections of this article will build three broad bridges from survey research to the core domains of Science II in general and to the cognitive neurosciences and to the area of biomedical and health research in particular. These three bridges should offer fresh incentives for pursuing and intensifying new ways of survey research both for generating data and for analyzing them.

\section{BRIDGES FROM THE COGNITIVE NEUROSCIENCES TO NEW COMPLEX INTERNAL ACTOR MODELS FOR SURVEY RESEARCH}

Following the new focus on living systems and the notion of embedded cognition, one of the basic differences between the old and the new background knowledge lies in the complex nature of cognitive processes of living systems. The study of cognition under Science II departs more and more from the pathways of conventional folk-psychology or from typical Science I traditions like behaviorism.

One of the challenging general heuristic rules for the study of cognitive processes called cognitive holism, was already included in Figure 1 and was propagated strongly as early as in 1969 by Heinz von Foerster (Foerster, 2003).

According to this rule, it is possible, in principle, to isolate conceptually certain components in the stream of cognitive 
DRUŠ. ISTRAŽ. ZAGREB GOD. 21 (2012), BR. 2 (116),

STR. 315-339

MÜLLER, K. H., TOŠ, N. NEW COGNITIVE... processes, for instance the faculty to perceive, the faculty to remember, ${ }^{9}$ the faculty to infer or many other senso-cognitive as well as cognitive-motoric faculties. However, one should not expect that these conceptual separations between perception, memory or inference find a 1:1 correspondence in the neural organization of actors. In its generalized form, the principle of cognitive holism can be formulated in the following way:

If one wishes to isolate these faculties functionally or locally, one is doomed to fail. Consequently, if the mechanisms that are responsible for any of these faculties are to be discovered, then the totality of cognitive processes must be considered ... (Foerster and Müller, 2003, 29f.) ${ }^{10}$

The inseparability of these faculties can be shown by a reduction ad absurdum. It can be demonstrated that the assumption of independent faculties in isolation leads to absurd consequences. In particular, it can be demonstrated that, if one of these faculties mentioned above is omitted, the entire system is devoid of cognition.

Phrased differently, actor models with one of the above faculties like actor models with memory only turn out strikingly incomplete because a variety of additional internal faculties are required in order to account for the capacity to memorize. Thus, cognitive holism poses a very big challenge for the development of new internal actor models. But once actor models that correspond to the principle of cognitive holism are available, a new bridge is opened up between survey research in general and between the interactions of respondents and interviewers in particular. As has already been demonstrated (Müller and Toš, 2009), these new interaction models, based, for example, on genetic algorithms, can offer profound new insights on the nature of survey questions and on several fallacies which result from a traditional folk-psychology view on domains like values or self-evaluations.

In particular, fully developed internal actor models could lead to a new typology of survey questions which is based on the cognitive production type of survey responses. In order to separate survey items into various groups, a new dimension can be introduced that refers to two different types of cognitive response productions, which have been labeled as over-learned and under-learned responses (Müller and Toš, 2009). Over-learned responses can be considered as relatively stable, constant and insensitive to different contexts or pre-histories of actors. Under-learned responses are, by necessity, creative, highly volatile, instable and sensitive to contexts or pre-histories. This distinction varies from one person to the other and it always involves the cognitive organization of ac- 
DRUŠ. ISTRAŽ. ZAGREB GOD. 21 (2012),

BR. 2 (116),

STR. 315-339

MÜLLER, K. H., TOŠ, N.: NEW COGNITIVE..

(1) TABLE 5

Over-Learned and

Under-Learned

Responses in Surveys

\begin{tabular}{lll}
\hline Dimensions & Over-Learned Responses & Under-Learned Responses \\
\hline Response & Single Response & Multiple Responses Possible \\
Response across Time & Stable across Time & Highly Volatile, Unstable \\
Inputs & No Sensitivity to & Highly Selective/Sensitive of \\
& Question Inputs & Question Inputs \\
Memory & Long-Term Memory & Short-Term Memory \\
Production & Recall & Just in Time Productions \\
Type of Task & Non-Creative & Creative \\
Context & Context-Free & Context-Sensitive \\
Path-Dependency & Path-Independent & Path-Dependent \\
State-Dependency & State-Independent & State-Dependent \\
Consistency & Global Consistency & Global, Local Inconsistencies \\
Errors by & Errors by Respondents & No Error by Respondents \\
Respondents & Possible & Possible \\
Bias & No Biases & Multiple Biases \\
Complexity & Trivial Configuration & Non-Trivial Configuration \\
\hline
\end{tabular}

One can introduce a second dimension with respect to different forms of observation, which becomes relevant for survey items. Along this second dimension, survey items can be differentiated between externally observable domains like recurrent practices which can be observed in principle by third parties and internal domains like assessments which rely predominantly on the respondents' answers alone. Survey items with externally observable domains can be validated with the help of other observational data whereas items with only internal domains offer no links to observable practices and 
(1) TABLE 6

A 2 × 2 Matrix

of Survey-ltems

It becomes highly interesting to arrange these two domains of cognitive response production and the two different types of observational domains. Table 6 presents such a matrix with four different groups of survey items.

\begin{tabular}{|c|c|c|}
\hline & $\begin{array}{l}\text { Externally Observable Domains } \\
\text { (Recurrent Practices, } \\
\text { Knowledge-Items, etc.) }\end{array}$ & $\begin{array}{l}\text { Internal Domains } \\
\text { (Assessments, Attitudes, } \\
\text { Fictional Stories, etc.) }\end{array}$ \\
\hline Over-Learned Responses & Group I & Group II \\
\hline Under-Learned Responses & Group III & Group IV \\
\hline
\end{tabular}

Due to the differentiations in Table 6, the interpretation of these-four groups of survey items should and must differ radically from one another.

- Group I-items can be interpreted at face-value and can be compared and checked with other external data as well with respect to measurement errors or biases. Items on the daily time from home to work, on information activities, on the voting behaviour or on knowledge-items fall under the first category. Unfortunately however, Group I-items are not the most common ones in surveys and are rather restricted to the socio-demographic section of surveys only.

- Group II-items, due to an internal cognitive production process only, cannot be linked with comparable external data sets, but may have similar data in the past or from other regions. Group II-items are also strongly connected with the long-term cognitive repertoire of actors, which manifests itself in these stable and context-independent responses. Most importantly, several additional items are usually needed to determine a Group II-membership of a particular item, otherwise a Group II-item becomes unidentifiable. While specific preferences or assessments might qualify as a Group II-item, Group II-items cannot be interpreted in terms of recurrent practices but must be understood as stable fixed-points in the cognitive domain of actors only.

- Group III-items are composed of externally observable survey questions which contain an unusual component like a particular scaling device. For example, asking for daily TV-consumption in terms of minutes requires a creative reaction and, thus, an under-learned response. Usually, Group III-items are characterized by weak links to recurrent practices, although additional external infor- 
DRUŠ. ISTRAŽ. ZAGREB GOD. 21 (2012)

BR. 2 (11 16$)$

STR. 315-339

MÜLLER, K. H., TOŠ, N.: NEW COGNITIVE.. mation on TV-consumption patterns for various TV-networks would be needed for any substantial interpretation. For Group III-items, additional external information is necessarily required in order to transform the weak links to recurrent practices into stronger ties.

- At first sight, Group IV-items look similar to the other three groups although these items are fundamentally different form the rest of the groups. Responses to these items are produced just in time, are forgotten almost instantly and, moreover, highly volatile and unstable within respondents. Trust in national or European institutions on a ten point scale can be considered as a paradigmatic example for a Group IV-item. In terms of interpretation, Group IV-responses offer no hints on recurrent practices and need, additionally, a large amount of similar cross-regional and inter-temporal data in order to identify a relevant explanandum at all. Persistent differences across and within countries on the trust in institutions-item, for example, makes it worthwhile to search for relevant external data on recurrent practices which are relevant for trust-issues. In a strong sense, Group IV-items by themselves are void of interpretative content.

This short typology of survey-items, based on a holistic cognitive actor model, makes three very clear points on the current distances between survey items and recurrent societal practices.

- First, relatively few survey-items, namely Group I-items only, allow a direct interpretation in terms of recurrent societal practices. Moreover, Group I-items can be analysed further with respect to significant differences in terms of class or stratification, gender differences or age groups.

- Second, Group II and Group III-items require a substantial amount of additional internal and especially external data in order to become interpretable at all. In combination with large external or internal data, these items can be interpreted at least in terms of weak ties to recurrent practices or the cognitive organization of respondents.

- Third, Group IV-items need an enormous amount of additional internal as well as external data in order to close the gap to observable recurrent societal routines at least in a weak sense. 
DRUŠ. ISTRAŽ. ZAGREB GOD. 21 (2012),

BR. 2 (116)

STR. 315-339

MÜLLER, K. H., TOŠ, N. NEW COGNITIVE..
The upshot of the typology of survey-responses lies in the observation that only a few items in traditional surveys can be interpreted directly with the help of statistical analyses. The majority of survey items, especially Group IV-items, need a large amount of additional external as well as internal data in order to be interpretable at all. However, surveys are usually interpreted as if they were composed of Group I-items only. In other words, by relying on surveys and the established forms of interpretation, a researcher positions her- or himself in relatively large distances to recurrent societal practices which, after all, were the target domain for surveys in the first place.

\section{BRIDGES FROM THE COGNITIVE NEUROSCIENCES TO NEW EXTERNAL ACTOR MODELS}

The second bridge is situated in the domain of actor-environment coupling and crosses the great divide between survey research and the fields of the cognitive neurosciences (Gazzaniga et al., 2004). The second bridge is built with the help of a well-known principle in the cognitive neurosciences which has been labeled as the principle of undifferentiated encodings PUE). PUE was postulated already by Johannes P. Müller in 1826 and has been put forward in recent decades again and again by Heinz von Foerster (e.g., Foerster, 2003) or Ernst von Glasersfeld (Glasersfeld, 1997). In order to describe PUE at greater length, it can be divided into three parts.

- Undifferentiated Signaling: The first part concerns the sensory border between actors and their environments and asserts that only undifferentiated quantities at different levels of intensities, but not qualitatively differentiated signals, cross the border between the external and the internal worlds of actors. Thus, sensory inputs enter as undifferentiated quantities and not as differentiated qualities.

The response of a nerve cell does not encode the physical nature of the agents that caused its response. Encoded is only 'how much' ..., but not 'what' (von Foerster, 2003, 215).

- Discrete Signaling: The second PUE-part stresses the fact that the quantities are not encoded in a continuous fashion, but in a discrete manner.

- Signal Integration: Finally, the third PUE-element emphasizes the necessity for an overall integration of sensory inputs into an overall pattern or result.

At first sight there are no family resemblances in view which could lead from the principle of undifferentiated en- 
DRUŠ. ISTRAŽ. ZAGREB GOD. 21 (2012), BR. 2 (116),

STR. 315-339

MÜLLER, K. H., TOŠ, N.: NEW COGNITIVE...

\section{FIGURE 3}

The Elements of the Principle of Undifferentiated Encoding (PUE) coding within the cognitive neurosciences to conventional survey research. Upon second thought however, the following methodological links can be identified which help to cross the distance between PUE in the cognitive neuroscience domains on the one hand and survey research on the other hand.

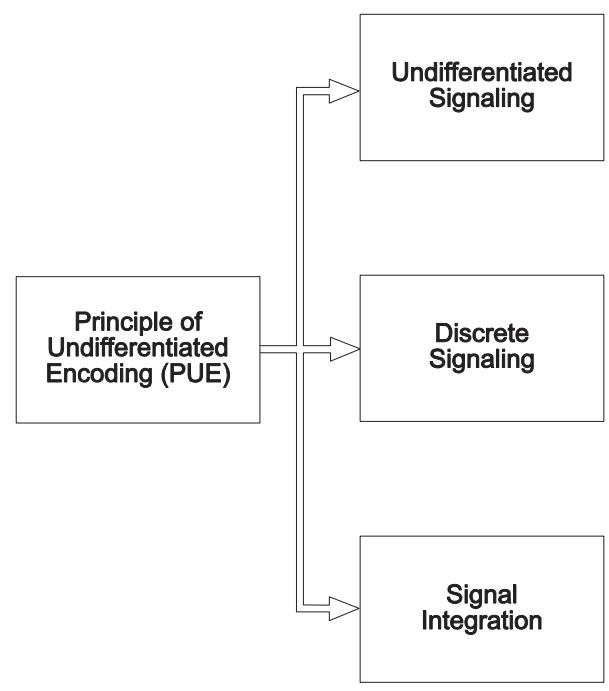

Due to PUE and the emphasis on undifferentiated signaling, a strong support can be offered for the functional equivalence of different dimensions within an identical broader survey domain. Surveys, by necessity, are capable of selecting only a small fraction of the daily routines and of their impact on the preferences and evaluations of individuals. Likewise, surveys are capable of identifying individual coping capacities in a highly selective manner, too. Thus, a single survey offers a highly selective minimal model of situated cognition (Robbins and Aydede, 2008; Piatelli-Palmarini, 1994; Pohl, 2004) which covers a small fraction of the overall stream of routines and of the cognitive evaluation patterns of actors.

PUE could and should open new bridges especially for a secondary analysis of seemingly incomparable data-sets which are characterized by different dimensions within an identical common domain. Here, PUE can be used to treat different dimensions within a commonly shared domain as equivalent. With discrete signaling one can build a discrete quantitative scale for qualitatively different inputs. And signal integration can be transformed into a special algorithm for all the aggregation of selected survey dimensions.

Table 7 offers an example for two common survey domains in Survey A and Survey B11 with different dimensions for each of the two common domains. 


\begin{tabular}{|c|c|}
\hline Survey A & Survey B \\
\hline \multicolumn{2}{|c|}{ Common Domain I: Working Conditions } \\
\hline Allowed to be flexible in working hours & Allowed to decide how daily work is organized \\
\hline Allowed to influence job environment & Allowed to influence decisions about work direction \\
\hline Allowed to change work tasks & Get a similar or better job with another employer \\
\hline Start own business & $\begin{array}{l}\text { Satisfaction with the way things are handled at } \\
\text { workplace }\end{array}$ \\
\hline \multicolumn{2}{|c|}{ Common Domain II: Resources } \\
\hline Household's total net income, all sources & Highest level of education \\
\hline $\begin{array}{c}\text { Borrow money to make ends meet, } \\
\text { difficult or easy }\end{array}$ & Feeling about household's income nowadays \\
\hline Life satisfaction & Happiness \\
\hline Father's highest level of education & Mother's highest level of education \\
\hline
\end{tabular}

(1) TABLE 7

PUE-Equivalent Item Batteries in Survey A and Survey B
Both surveys offer a functionally equivalent account of the overall neuro-cognitive pattern of undifferentiated encodings, discrete signaling and the signal integration between the cognitive-neural organization of actors and their socio-economic environments.

Due to the rich availability of different dimensions within a set of common domains, one could produce new, but identically generated group formations which can be used for comparative analysis, despite significant differences in the underlying dimensions. Due to PUE, these constructs can be considered as equivalent in terms of their overall neuro-cognitive repercussions and implications. Thus, through the PUE-bridge a large number of new designs for secondary analyses should be opened up because one can use different dimensions in surveys that share a set of common domains and aggregate them in an identical manner (see Bischof et al., 2009).

\section{NEW BRIDGES FROM SURVEY RESEARCH TO THE BIOMEDICAL SCIENCES}

The third new bridge leads from designs for survey analysis to the areas of biomedical and health research. Through this bridge one can move from various domains of vertical socio-economic dimensions, from socio-economic inequalities as well as the self-reported health status to a deeper language level and to a homogeneous vocabulary of stressors and of neuro-immunological processes.

Initially, it is useful to start with a taxonomy of different types of stressors which can be found within the relevant body of literature (see, for example, Cooper, 1996; Horwitz and Scheid, 1999, or Sarafino, 2002). Here, one is confronted with 
DRUŠ. ISTRAŽ. ZAGREB GOD. 21 (2012),

BR. 2 (116)

STR. 315-339

MÜLLER, K. H., TOŠ, N.: NEW COGNITIVE... a heterogeneous set, comprised of sensory stressors (strong light, noise, sensory deprivation, etc.), block-stressors (preventing essential routines like eating, sleeping, social contacts, etc.), achievement stressors (tests, examinations, work-tasks, but also monotony at work, etc.), social stressors (large crowd of people, loneliness, isolation, etc.), environmental stressors (noise, pollution, toxic materials, etc.), decision-based stressors (goal conflicts, quick decisions, but also lack of decision-making, etc.) or future-based stressors (fear, anxiety of the future, etc.).

Seemingly, the heterogeneity of stressors is accompanied by a heterogeneity of stress reactions which vary in time (minutes, hours, days, weeks ...), in intensity or in emotions, associated with each stress reaction. Nevertheless, common to all these stress reactions is an attempt to reduce the discrepancy between the effects of stressors and internal target values. Moreover, all stress reactions involve the activation of the hypothalamus-pituitary-adrenal axis and produce comparatively high quantities of endocrine hormones, particularly corticosteroids, with cortisol as the most important one, and catecholamines. Likewise, all physiological reactions to stress manifest themselves in a broad range of measurable changes like a higher production of stress hormones, higher degrees of blood pressure, heart rate, respiration rate, galvanic skin responses or, in larger amounts, of free fat acids.

The general pattern of stress responses possesses at least two main connections to the domain of sickness and ailments, namely through their direct effects on the cardiovascular system on the one hand, and through their immediate impact on the immune system on the other hand.

With the short background on stress-research, it appears plausible to create a bridge from survey research to special classes of stressors like social, environmental, future-based or decision-based stressors. In order to move along this bridge, one needs a special subset of survey dimensions which are linked to societal inequality. In particular, the lower segments of dimensions like degree of education, income, but also working conditions, work autonomy or environmental constraints like pollution or traffic noise can be seen as external determinants of societal inequalities. From this perspective, the following subset-relation can be put forward:

\section{Lower Segments SL of Dimensions of Societal Inequalities $\subset$ Stressors}

It is quite obvious that this subset-relationship needs a very detailed justification which cannot be provided within the framework of the present article. However, five main arguments can be given, however, which should offer some plau- 
DRUŠ. ISTRAŽ. ZAGREB GOD. 21 (2012), BR. 2 (116)

STR. 315-339

MÜLLER, K. H., TOŠ, N. NEW COGNITIVE... sibility for a sub-set relation between SL, the lowest decile, lowest quarter up to the lower third in the different dimensions of societal inequalities and stressors.

- First, SL-positions, which can be specified in a wide array of living and working conditions, are characterized, inter alia, by their relative permanence. Thus, many of the SL-parts of socio-economic inequality dimensions like low, insufficient or deteriorating incomes or low degrees of qualifications are to be classified as long-lasting or, like in the case of low qualifications, as (nearly) permanent. Thus, being positioned in the SL-parts normally acts as a continuous stressor and not as a single, rare or isolated occurrence.

- Second, there exists a remarkable symmetry between the language of societal inequality, in particular the focus on the lower parts of a distribution on the one hand and the physiological stress language on the other hand. In both cases, no equivalences can be found for the upper side of the inequality dimensions. Feeling unsafe in the public sphere does have a corollary in terms of stressors. But feeling very safe in the public domain does not constitute an alternative source for stressors. Likewise, a noisy environment at the workplace or at home implies at the same time an environmental stressor whereas a quiet atmosphere at work or at home cannot be associated with a different group of stressors. Thus, the lower segments of the distribution of inequality dimensions can be linked to stressors, whereas upper segments in the distribution imply, by and large, the absence of stressors.

- Third, the distribution-dependent specification for thresholds for the SL-parts provides additional support for the subset relationship between the $\mathrm{S}^{\mathrm{L}}$-areas of dimensions of societal inequality and stressors. Since the majority of the population is, by definitional necessity, above the SL-threshold, individual actors, falling in a specific SL-part, perceive themselves usually relatively deprived. Thus, the available literature on the importance of relative deprivation (Olson and Hafer, 1996 or Walker and Pettigrew, 1984) can be added as further evidence for the proposed SL-part-stress linkages.

- Fourth, while stress reactions vary in length, intensity and emotional involvement, the basic physiological reaction patterns are unspecific with respect to the sources of stress. In other words, one does not find a "bad boss-stress 
DRUŠ. ISTRAŽ. ZAGREB GOD. 21 (2012),

BR. 2 (11)

STR. 315-339

MÜLLER, K. H., TOŠ, N.: NEW COGNITIVE. reaction", confined to a specific region in the neuro-immune system in contrast to a "loud noise-stress reaction", affecting other parts of the neuro-immune system. Thus, a multi-dimensional array of essential living conditions across the contexts or settings of actors and across their cognitive-emotional organization can be interpreted as a summary of all relevant potential stressors whose scope and degree of completeness is limited by the restrictions inherent in conventional survey research only.

- Fifth, stressors and stress reaction are clearly not invariant to the actual number of stressors since stress reactions are functionally related, probably in a complex and non-linear manner, to the overall number of stressors. This, in turn, provides additional support why a survey analysis should focus on the aggregation of dimensions because these aggregate values should be interpretable in terms of a net value for the overall number of socio-economic stressors.

In this way, a third bridge can be built which leads from survey research to biomedical and health research and back and which should lead to a much deeper understanding of the complex interactions between daily routines at the workplace or at home and on patterns of health conditions.

\section{FURTHER OUTLOOKS}

At this point, the question arises whether these three bridges from the neuro-cognitive sciences to survey research should be viewed as artificial constructs with zero consequences, as a happy coincidence or as a preliminary set of successful examples with many more to come. Towards the end of this article two strong arguments can be put forward that one should be able to identify many more recombinations across survey research, the neuro-cognitive sciences and the life sciences in the future. These two basic arguments do not even depend on the secular changes from Science I to Science II, but refer to the underlying technological support systems and environments.

- First, in a sharp contrast to the laboratories for most parts of the 20th century, one can observe a revolution in cyber-research infrastructures which started only in the last two decades and which will provide, inter alia, a huge potential for data-integration and model recombinations across practically all scientific disciplines. The cyber-research infrastructures, which are currently built across various fields of science are, in principle, accessible 
DRUŠ. ISTRAŽ. ZAGREB GOD. 21 (2012), BR. 2 (116)

STR. 315-339

MÜLLER, K. H., TOŠ, N. NEW COGNITIVE... from every point of the scientific landscapes. Thus, a massive integrative support system is currently in construction which, even in the case of a chronic under-utilization, provides a permanent incentive to explore new and inter- or transdisciplinary ways of data or theory integration.

- Second, one can also see an upward trajectory of the information and communication technologies (ICT) from its low levels of numerical operations to considerably higher levels of complex task integrations. Along this path the ICT-segment produces recombinant and increasingly intelligent machines that move along the drift of cognitive holism, which has been described in the fourth section of this article. As a consequence, a rich class of machine-based, but cognitive-holistic actor models, which can also be used as reference points for survey research, will be developed in the near future.

And with this brief technological outlook, the current article on the impact of new building blocks in the background knowledge for survey research can and will be concluded.

\section{NOTES}

1 On this phase transition from Science I to Science II across different dimensions of the science landscape, see especially Hollingsworth and Müller, 2008 as well as Hollingsworth et al., 2008 or 2010.

2 For a similar distinction between Mode I and Mode II see, for example, Gibbons et al., 1994, Nowotny et al., 2001 or Nowotny, 1999 and 2005.

${ }^{3}$ On a wider discussion of the ongoing transformations from Science I to Science II, see especially Boyer, 2008, Mayntz, 2008, Nowotny, 2008 or Sornette, 2008. While Mode I and Mode II refer more to the organizational changes in science, the differentiation between Science I and Science II is more focused on the theoretical dynamics of the overall science landscapes.

4 On characteristic differences between the operation rules in high energy physics and molecular biology, see especially Knorr-Cetina, 1999.

5 On radical constructivism in general, see Watzlawick, 1981, Watzlawick and Krieg, 1991 or Schmidt, 1987 which paved the way for radical constructivism as a wider research tradition.

${ }^{6}$ Second-order cybernetics has been developed explicitly by Heinz von Foerster as a science of living systems for living systems. See especially Foerster, 2003, Müller and Müller, 2007 and Müller, 2008.

7 See also the paper from 1976 by Francisco J. Varela, where he moves beyond the usual dualistic suspects of observer/observed, subject/ object, describer/described, operator/operand and the like (Varela, 1976).

8 Among the many variants of a theorem on the necessary emergence of Eigenforms, see, for example, Francisco Varela and Joseph Goguen's version 1979. 
DRUŠ. ISTRAŽ. ZAGREB GOD. 21 (2012), BR. 2 (116),

STR. 315-339

MÜLLER, K. H., TOŠ, N.: NEW COGNITIVE..

\section{REFERENCES}

${ }^{9}$ In principle, it would be possible to differentiate between a large number of these faculties, like the faculty to infer, the faculty to learn, the faculty to evaluate, the faculty to communicate or the faculty to move, to name just a few more additional faculties.

${ }^{10}$ Aside from the functional and the local theses, one could put forward two additional theses, one on genetic holism and one on epistemological holism as well. For more details, see Foerster and Müller, 2003.

11 Survey A and Survey B both use different items form the European Social Survey (ESS). This procedure was taken in order to demonstrate the comparability between these different dimensions within a common domain. For more details, see Müller et al., 2010.

Adams, F. and Aizawa, K. (2008), The Bounds of Cognition, Chichester, Wiley Blackwell.

Bischof, C., Miheljak, V., Müller, K. H. and Toš, N. (2009), The Third Road to Comparative Research: Morphological Designs. In: N. Toš, K. H. Müller et al. (eds.), Three Roads to Comparative Research (pp. 425-467), Wien, Edition Echoraum.

Bodenhausen, G. V. and Lambert, A. J. (eds.) (2003), Foundations of Social Cognition. A Festschrift in Honor of Robert S. Wyer, New York, Lawrence Erlbaum.

Boyer, R. (2008), The Quest for Theoretical Foundations of Socio-Economics: Epistemology, Methodology or Ontology? In: Discussion Forum: On Rogers Hollingsworth and Karl H. Müller, Transforming Socio-Economics with a New Epistemology. Socio-Economic Review, 6 (4): 733-746.

Cooper, C. L. (ed.) (1996), Handbook of Stress, Medicine, and Health, Boca Raton, CRC Press.

Elsasser, W. M. (1998), Reflections on a Theory of Organisms. Holism in Biology, Baltimore, The Johns Hopkins University Press (orig. 1987).

Foerster, H. v. (2003), Understanding Understanding: Essays on Cybernetics and Cognition, New York, Springer.

Foerster, H. v. and Müller, K. H. (2003), Action without Utility. An Immodest Proposal for the Cognitive Foundation of Behavior. Cybernetics and Human Knowing, 3-4 (10): 27-50.

Gazzaniga, M. S., Bizzi, E. and Black, I. B. (eds.) (2004), The Cognitive Neurosciences III, Cambridge, The MIT Press.

Gibbons, M., Limoges, C., Nowotny, H. et al. (1994), The New Production of Knowledge. The Dynamics of Science and Research in Contemporary Societies, London, Sage Publications.

Gibbs, R. W. (2005), Embodiment and Cognitive Science, Cambridge, Cambridge, University Press.

Glasersfeld, E. v. (1997), Radikaler Konstruktivismus. Ideen, Ergebnisse, Probleme, Frankfurt, Suhrkamp.

Goguen, J. and Varela, F. (1979), Systems and Distinctions: Duality and Complementarity. International Journal of General Systems, 5 (1): 31-43. doi:10.1080/03081077908960886 
DRUŠ. ISTRAŽ. ZAGREB GOD. 21 (2012), BR. 2 (116), STR. 315-339

MÜLLER, K. H., TOŠ, N. NEW COGNITIVE...
Hollingsworth, J. R. and Müller, K. H. (2008), Transforming Socio-Economics with a New Epistemology. Socio-Economic Review, 6 (3): 395-426. doi:10.1093/ser/mwn006

Hollingsworth, J. R., Müller, K. H., Hollingsworth, E. J. and Gear, D. M. (2008), Socio-Economics and a New Scientific Paradigm. In: H. Flam and M. Carson (eds.), Rule Systems Theory. Applications and Explorations (pp. 39-56), Frankfurt, Peter Lang Verlag.

Hollingsworth, J. R., Müller, K. H., Hollingsworth, E. J. and Gear, D. M. (2010), Socio-Economics and a New Scientific Paradigm. In: L. Kajfež-Bogataj, K. H. Müller, I. Svetlik and N. Toš (eds.), Modern RISC-Societies. Towards a New Paradigm for Societal Evolution (pp. 437-460), Wien, Edition Echoraum.

Horwitz, A. V. and Scheid, T. L. (eds.) (1999), A Handbook for the Study of Mental Health. Social Contexts, Theories, and Systems, Cambridge, Cambridge University Press.

Knorr-Cetina, K. (1999), Epistemic Cultures. How the Sciences Make Knowledge, Cambridge, Harvard University Press.

Kuhn, T. S. (1973), Die Struktur wissenschaftlicher Revolutionen, Frankfurt, Suhrkamp.

Kuhn, T. S. (1977), Die Entstehung des Neuen. Studien zur Struktur der Wissenschaftsgeschichte, Frankfurt, Suhrkamp.

Maturana, H. R. (1985), Comment by Humberto R. Maturana: The Mind Is Not the Head. Journal of Social and Biological Structures, 8 (4): 308-310. doi:10.1016/0140-1750(85)90033-8

Maturana, H. R. (1985a), Erkennen: Die Organisation und Verkörperung von Wirklichkeit. Ausgewählte Arbeiten zur biologischen Epistemologie, second edition, Braunschweig, Friedr. Vieweg\&Sohn.

Maturana, H. R. and Varela, F. J. (1987.), Der Baum der Erkenntnis. Die biologischen Wurzeln des menschlichen Erkennens, Bern, Scherz.

Mayntz, R. (2008), Networks and Self-Organization: Dissecting the Model of Complex Networks. In: Discussion Forum: On Rogers Hollingsworth and Karl H. Müller, Transforming Socio-Economics with a New Epistemology. Socio-Economic Review, 6 (3): 750-754.

McCulloch, W. S. (1988), A Heterarchy of Values Determined by the Topology of Nervous Nets. In: W. S. McCulloch, Embodiments of Mind (pp. 40-45), Cambridge, The MIT Press.

Müller, A. and Müller K. H. (eds.) (2007), An Unfinished Revolution? Heinz von Foerster and the Biological Computer Laboratory, 1958 - 1976, Vienna, Edition Echoraum.

Müller, K. H. (2008), The New Science of Cybernetics. The Evolution of Living Research Designs, Vol. I: Methodology, Vienna, Edition Echoraum. Müller, K. H. (2011), The New Science of Cybernetics. The Evolution of Living Research Designs, Vol. II: Theory, Vienna, Edition Echoraum.

Müller, K. H. and, Toš, N. (2009), Towards New Frontiers in Comparative Survey Research. In: N. Toš, K. H. Müller et al. (eds.), Three Roads to Comparative Research. Analytical, Visual, Morphological (pp. 461-505), Wien, Edition Echoraum.

Müller, K. H., Toš, N. and Bischof, C. (2010), Towards New Forms of Secondary Analyses for Survey Data. e-WISDOM, 3: 61-97. 
DRUŠ. ISTRAŽ. ZAGREB GOD. 21 (2012) BR. 2 (116),

STR. 315-339

MÜLLER, K. H., TOŠ, N.: NEW COGNITIVE..
Noe, A. (2009), Out of Our Heads. Why You Are Not Your Brain, and Other Lessons from the Biology of Consciousness, New York, Hill and Wang.

Nowotny, H., Scott, P. and Gibbons, M. (2001), Re-Thinking Science. Knowledge and the Public in an Age of Uncertainty, Cambridge, Polity Press.

Nowotny, H. (1999), Es ist so. Es könnte auch anders sein, Frankfurt, Suhrkamp.

Nowotny, H. (2005), Unersättliche Neugier. Innovation in einer fragilen Zukunft, Berlin, Kadmos.

Nowotny, H. (2008), Bargaining, Not Borrowing: On Problem Choice and Problem Space. In: Discussion Forum: On Rogers Hollingsworth and Karl H. Müller, Transforming Socio-Economics with a New Epistemology. Socio-Economic Review, 6 (3): 754-759.

Olson, J. M. and Hafer, C. L. (1996), Affect, Motivation and Cognition in Relative Deprivation Research. In: R. M. Sorrentino and E. T. Higgins (eds.), Handbook of Motivation and Cognition: The Interpersonal Context, Vol. 3 (pp. 85-117), New York, Guilford.

Palombo, S. R. (1999), The Emergent Ego: Complexity and Coevolution in the Psychoanalytic Process, Madison, International Universities Press.

Piatelli-Palmarini, M. (1994.), Inevitable Illusions. How Mistakes of Reason Rule Our Minds, New York, John Wiley \& Sons.

Pohl, R. F. (ed.) (2004.), Cognitive Illusions. A Handbook on Fallacies and Biases in Thinking, Jusgement and Memory, Hove, Psychology Press.

Robbins, P. and Aydede, M. (eds.) (2008), The Cambridge Handbook of Situated Cognition, Cambridge, Cambridge University Press.

Rosen, R. (2005), Life Itself: A Comprehensive Inquiry into the Nature, Origin, and Fabrication of Life, New York, Columbia University Press.

Ryckman, R. M. (2000), Theories of Personality, Belmont, Wadsworth Publishers.

Sarafino, E. P. (2002), Health Psychology. Biopsychosocial Interactions, fourth edition, New York, John Wiley\&Sons.

Schmidt, J. S. (ed.) (1987), Der Diskurs des Radikalen Konstruktivismus, Frankfurt, Suhrkamp.

Sornette, D. (2008), Interdisciplinarity in Socio-Economics, Mathematical Analysis and the Predictability of Complex Systems. In: Discussion Forum: On Rogers Hollingsworth and Karl H. Müller, Transforming Socio-Economics with a New Epistemology. Socio-Economic Review, 6 (3): 759-770.

Varela, F. J. (1976), Not One, not Two: Position Paper for the Mind-Body Conference. Co-Evolution Quarterly, 3: 62-67.

Walker, I. and Pettigrew, T. F. (1984), Relative Deprivation Theory: An Overview and Conceptual Critique. British Journal of Social Psychology, 23 (4): 301-310. doi:10.1111/j.2044-8309.1984.tb00645.x

Watzlawick, P. (ed.) (1981), Die erfundene Wirklichkeit. Wie wissen wir, was wir zu wissen glauben? Beiträge zum Konstruktivismus, München, Piper.

Watzlawick, P. and Krieg, P. (eds.) (1991), Das Auge des Betrachters. Beiträge zum Konstruktivismus. Festschrift für Heinz von Foerster, München, Piper. 
DRUŠ. ISTRAŽ. ZAGREB GOD. 21 (2012), BR. 2 (116),

STR. 315-339

MÜLLER, K. H., TOŠ, N. NEW COGNITIVE...

\section{Anketno istraživanje u novim kognitivnim okruženjima drugoga doba znanosti}

Karl H. MÜLLER

Bečki institut za dokumentaciju i metodologiju

društvenih znanosti, Beč

Niko TOŠ

Fakultet društvenih znanosti, Ljubljana

Članak se bavi brzim promjenama koje se trenutačno šire područjem znanosti te raspravlja o dalekosežnim posljedicama ovoga strukturnog prijeloma za društvene znanosti i, posebno, za anketno istraživanje. Točnije, ovaj članak izlaže tri osnovne tvrdnje. Prvo, cijeli se sustav znanosti danas nalazi u važnoj prijelaznoj fazi koju možemo sažeto nazvati pomakom od prvoga doba znanosti u drugo doba. Drugo, zbog tih velikih promjena, postupno nastaju nova kognitivna okruženja, koja će u svojstvu temeljnih znanja o anketnom istraživanju duboko utjecati na buduću praksu. Treće, ova nova kognitivna okruženja stvorit će nove modele-sudionike i nove mostove između anketnog istraživanja i kognitivnih neuroznanosti s jedne strane i biomedicinskih istraživanja s druge.

Ključne riječi: dugoročna dinamika znanosti, kognitivne neuroznanosti, temelina znanja, anketno istraživanje, biomedicinska istraživanja 